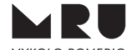

MYKOLO ROMERIO
UNIVERSITETAS

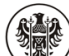

Uniwersytet Wrocławski
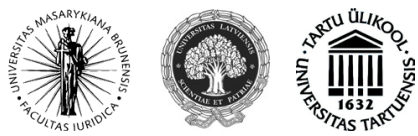

ISSN 1392-6195 (print) ISSN 2029-2058 (online) JURISPRUDENCIJA JURISPRUDENCE 2014, 21(2), p. 484-505.

\title{
JUDICIAL ERRORS IN CIVIL PROCEEDINGS: CONCEPT, CAUSES AND PROCEDURAL METHODS OF THEIR PREVENTION
}

\author{
Nelia Savchyn \\ Yuriy Fedkovych Chernivtsi National University \\ Kotsubinsky str. 2, 58012, Chernivtsi, Ukraine \\ Tel.: +380 372526235 \\ E-mail: office@chnu.edu.ua
}

Submitted on 31 January, 2014; accepted on 30 May, 2014

doi:10.13165/JUR-14-21-2-08

\section{Introduction}

Maintaining effectiveness of Ukrainian statehood and the legal system in particular is a challenge that notably stands out among a variety of critical problems nowadays. This issue is also entirely relevant within Ukrainian judiciary, including the branches that are responsible for civil litigations. Therefore, nowadays ensuring the availability of jurisdiction is not enough, it is important to guarantee its effectiveness, as well.

Article 55 of the Constitution of Ukraine stipulates that everyone is entitled to judicial protection of their rights and freedoms ${ }^{1}$. To further the development of this

1 Konstytucija Ukrai'ny [Constitution of Ukraine]. Ukraine, 1996, No. 245k/96-VR [interactive]. [accessed on 2014-01-11]. <http://zakon0.rada.gov.ua/laws/show/254\%D0\%BA/96-\%D0\% B2\%D1\%80>.

Jurisprudencija/Jurisprudence

(C) Mykolo Romerio universitetas, 2014

(C) Mykolas Romeris University, 2014
ISSN 1392-6195 (print), ISSN 2029-2058 (online) http://www.mruni.eu/lt/mokslo_darbai/jurisprudencija/ http://www.mruni.eu/en/mokslo_darbai/jurisprudencija/ 
constitutional provision, the current legislation grants every person the right to go to court for protection of their violated, unrecognized or disputed rights, freedoms or interests as per the procedure established in the Civil Procedure Code of Ukraine (further - the CPC of Ukraine or the Civil Procedure Law)2.

According to Article 1 of the CPC of Ukraine as of March 18th 2004, the main function of the civil litigation is a just, impartial and timely consideration and resolution of civil proceedings aimed at protecting violated, unrecognised or contested rights, liberties or interests of individuals, the rights and interests of legal entities, interests of states ${ }^{3}$. However, when a judicial error occurs, the judge renders illegal and unjustified judgement, which consequently hinders the achievement of civil litigation objectives.

The elimination of judicial errors is of great importance in the procedural doctrine and jurisprudence nowadays. More so, it should be agreed with the opinion of N.I. Tkacheva about the fact that removing judicial errors through vitiation and modification of the ruling "is an undesired extreme measure as act of justice and it shouldn't be viewed as a standard occurrence (in terms of legal regulation), but rather as an exceptional one"4. Thus, it is evident that in order to increase the effectiveness of civil litigation, preventive methods should be considered equally important to the elimination methods of judicial errors.

Outlining and conducting an academic research on preventive methods of judicial errors in the process of rendering justice in civil proceedings is of outmost importance.

The aim of this article is to outline the definition of judicial error and pointing of causes of their origin, and also to outline the definition and significance of procedural methods for judicial errors prevention in civil litigation, covering the classification and analysis of those methods.

The research subjects are the following ones: 1) a legal doctrine that defines the meaning of judicial error, causes of their origin and preventive methods aimed at avoiding judicial errors in civil proceedings; 2) active Civil Procedure Law of Ukraine that determines the main methods for judicial errors prevention; 3 ) jurisprudence in civil litigation

2 Cyvil'nyj procesual'nyj kodeks Ukrai'ny [Civil Procedure Code of Ukraine]. Ukraine, 2004, No. 1618-IV [interactive]. [accessed on 2014-01-11]. <http://zakon1.rada.gov.ua/laws/show/1618$15>$. Ibid.

4 Tkachev, N. I. Kachestvo processual'noj dejatel'nosti kak rezul'tat realizacii prava na sudebnuju zashhitu. Problemy i sootnoshenie [Tkachev, N.I. The Quality of Procedural Activities as a Result of Recognition of the Right for Judicial Protection. Issues and Values]. Teorija i praktika prava na sudebnuju zashhitu i ee realizacija $v$ grazhdanskom processe. Mezhvuzovskij sbornik nauchnyh trudov [The Theory and Practice of the Right for Judicial Protection and Its Execution in the Civil Process. Inter-University Collection of Scientific Research]. Saratov, 1991, p. 27. 
The methods used in the course of this research are philosophical methods of knowledge acquisition (dialectic, hermeneutical, necessitarian), general scientific methods (analysis, synthesis, generalization, systematic method), private research methods (comparative legal, sociological, statistical, historical, formal logic, functional).

The concept of judicial error, causes of their origin and methods of prevention of judicial errors in civil litigation were analysed in the research works of the following academics: W. Burnham, N.N. Efremova, A.S. Grytsanov, P.P. Kolesov, E.V. Lapshynov, V.M. Lebedev, E.V. Leontiev, A.B. Lisytkin, I.B. Mikhailovska, K.R. Mursalimov, Y.A. Popova, S.V. Praskova, Y.M. Rudenko, V.V. Samsonov, S.K. Strunkov, N.I. Tkachev, L.V. Trofimova, E.V. Vaskovskyy, A.A. Vlasov, N.N. Voplenko, O.F. Voronov, I.M. Zaitsev, G.A. Zhylin and others.

\section{The main text}

A judicial error is a result of unlawful actions that fail to meet the set goals. They are related to inaccuracy of actions, inadequacy in thinking and are expressed in the violation of law regulations. A judicial error is regarded as a defective legal fact within the proceeding that violates legal norms. An error is defined as inaccurate knowledge of the actual circumstances, legal regulations, rights and obligations of the court to carry out proceedings, which results in an unlawful procedural act ${ }^{5}$.

In legal literature and jurisprudence, the "judicial error" category is widely used to characterize various kinds of flaws in judicial operations. In particular, A.A. Vlasov pointed out that "judicial error" is a broad category that covers both the violations that prevent timely resolution of the case, as well as those that prevent its proper consideration. The latter can be split into illegal and unjustified cases. Illegality is the result of improper use or non-use of substantive or procedural law ${ }^{6}$.

Law enforcement (including judiciary) error is defined by N.N. Voplenko as "a result of sovereign operations of specific objects of law enforcement that are contradictory to the norms of substantive or procedural law and don't meet the actual goals of legal regulations, that is qualified as erroneous by the competent entity in a specific act"7.

5 Leont'ev, E. V. Oshibka sud'i v mehanizme realizacii norm grazhdanskogo processual'nogo prava [Leontiev, E.V. Judicial Error in the Mechanism of Civil Procedure Law Enforcement] Materialy nauch.-prakt. konf., posvjashhennoj 80-letiju professora M. A. Vikut; otv. red N.V. Kuznecov [Sicent. Pract. Conf. Materials, Dedicated to 80th Anniversary of Professor M. A. Vykut; edited by N.V. Kusnetsov]. Saratov: Izdatel'stvo GOU VPO "Saratovskaja gosudarstvennaja akademija prava", 2003, p. 130.

6 Vlasov, A. A. Grazhdanskoe processual'noe pravo: Uchebnik [Vlasov, A.A. Civil Procedure Law: Textbook]. Moskva: TK Velbi, 2004, p. 335.

7 Voplenko, N. N. Oshibki v pravoprimenenii: ponjatie i vidy [Voplenko, N.N. Law Enforcement Errors: Concept and Types]. Sov. gosud. i pravo [Sov. State and Law]. 1981, 4: 38-46. 
G.A. Zhylin notes that judicial error in a civil case is nothing but a discrepancy between the result of the procedural operations of the court and the target regulations of a civil proceeding, stipulated in the norms of the Civil Procedure Code ${ }^{8}$.

I.M. Zaitsev defines judicial error as actions or a result of actions of court officials that are not aligned with the goals of justice'. Judicial errors are the "misconducts (actions, results of actions) that are indicative of failure to achieve justice regulations" ${ }^{10}$. In his opinion, the term "judicial errors" is characterized as follows:

1) they are a violation of legal norms and an indication of deviations from the targets of civil procedure;

2) they can occur in courts and as a result of actions of the judges that are appointed to consider and resolve civil cases;

3) all errors can be eliminated through legislation following civil judicial order ${ }^{11}$.

E.V. Leontiev suggested referring judicial error to the scope of intellectual (cognitive) actions of the judge, and the rulings that are issued as a result of such error to the procedural field. Inaccurate knowledge becomes an error when it migrates from the phase of development into a fixed phase (internal opinion), based on which the court conducts an unlawful procedural act. The court as a state entity is not the subject of an error, but the judge as a person endowed with consciousness and will is $^{12}$.

According to Y.M. Rudenko, a judicial error is a procedural act of the court (judge) associated with the wrong perception, analysis or conduct of law regulations, deviation from the principles of justice, which occurs in the court ruling that has the bases for cancelation or alteration, as it is violating the rights, freedoms and legitimate interests of the parties and (or) other people involved in the case ${ }^{13}$.

8 Zhilin, G. A. Celevye ustanovki grazhdanskogo sudoproizvodstva i problema sudebnoj oshibki [Zhylin, G.A. Target Regulations in Civil Proceedings and the Problem of Judicial Error]. Gosudarstvo i pravo [State and Law]. 2000, 3: 51-58.

9 Zajcev, I. M. Teoreticheskie voprosy ustranenija sudebnyh oshibok $v$ grazhdanskom processe. Avtoreferat diss. ... d-ra jurid. nauk [Zaycev, I.M. Theoretic Questions on Judicial Error Elimination in Civil Proceedings. Autoref. diss. PhD in law science]. Saratov, 1987, p. 8.

10 Zajcev, I. M. Sudebnye oshibki [Zaycev, I.M. Judicial Errors]. Sovershenstvovanie zakonodatel'stva $i$ pravoprimenitel'noj dejatel'nosti [Improving the Legislation and Law Enforcement Operations]. Jaroslavl', 1989: 90-94.

11 Vikut, M. A., and Zajcev, I. M. Grazhdanskij process Rossii: Uchebnik [Vykut, M.A., and Zaycev, I.M. Civil Procedure in Russia: Textbook]. Moskva: Jurist, 1999, p. 304.

12 Leont'ev, E. V. Sudebnaja oshibka v grazhdanskom processe: Ponjatie i harakternye cherty [Leontiev, E.V. Judicial Error in the Civil Process: Concept and Characteristics]. Sbornik "Sovremennye problemy grazhdanskogo prava i processa" [Collection "Current Issues in Civil Procedure Law"]. Novosibirsk, 2002: 186-189.

13 Rudenko, Ju. M. Dejatel'nost' advokata po preduprezhdeniju, vyjavleniju i ispravleniju sudebnyh oshibok v grazhdanskom sudoproizvodstve (organizacionno-pravovoj aspekt). Diss. kand. jurid. nauk [Rudenko, Y.M. The Actions of a Lawyer on Prevention, Identification and Correction of 
L.V. Trofimova defines a judicial error as wrong actions of court officials that hurdle the achievement of a set goal causing negative consequences, including cancelation of an erroneous ruling ${ }^{14}$.

In the present paper author's opinion, a judicial error is an unlawful act (inaction) of the authorized entity (the judge), occurring regardless of his intention, outlined in a specific procedural document, that violates the procedural and (or) substantive laws, results in a failure to achieve the goals and carry out the duties of the procedural litigation, as a result of which a specific court ruling can be vitiated or modified either by a higher court or by issuing court (correction of typographical and arithmetic errors, additional ruling, judgement clarification).

There are no occurrences or events in the world that would not have a cause for their emergence or existence. A judicial error also has defined reasons of its emergence and existence. The analysis of causes of judicial errors has an important practical meaning as it allows creating methods of organisational, legal and procedural character for elimination and prevention of judicial errors. Identifying the causes of judicial errors is useful not only for elimination of judicial errors, but also for prevention of their occurrence.

In judicial practice, procedural violations are considered to be causes of illegal or unjustified case rulings, when the judge or the court does certain things incorrectly or fails to carry out certain actions, as a result of which the court ruling is subject to cancelation or alteration.

Different authors outline various causes of judicial errors, the examples of which are the following:

1) excessive pressure on judges ${ }^{15}$;

2) instability and absence of equal application of law in judicial practice, constant renewal of legislation, absence of latest information about the practice of new legislation application, conceptually outdated procedural laws ${ }^{16}$;

3) lack of high-level training and education for judges, lack of informing of judges, missing equal interpretation and application of the law ${ }^{17}$;

Judicial Errors in Civil Proceedings (Organizational-Legal Aspect). Diss. cand. legal sciences]. Moskva, 2009, p. 36.

14 Trofimova, L. V. Osnovanija k otmene sudebnyh reshenij, ne vstupivshih v zakonnuju silu. Diss. ... kand. jurid. nauk [Trofimova, L.V. Grounds for Annulment of Court Rulings that Were not Legally Enforced. Diss. ... cand. legal sciences]. Saratov, 1999, p. 130.

15 Zhilin, G. A. Zashhita prav cheloveka v grazhdanskom sudoproizvodstve [Zhylin, G.A. Protection of Human Rights in Civil Proceedings]. Rossijskaja Justicija [Russian Justice]. 1998, 1: 5-7.

16 Lebedev, V. Ot koncepcii sudebnoj reformy $\mathrm{k}$ novym idejam razvitija sudebnoj sistemy [Lebedev, V. From the Concept of Judicial Reform to New Ideas on Development of the Judicial System]. Rossijskaja justicija [Russian Justice]. 2000, 3: 2-5.

Ot reformirovanija k sovershenstvovaniju sudebno-arbitrazhnoj sistemy, ukrepleniju nezavisi- 
4) imperfect procedural legislation, unsatisfactory financial and logistics supply of courts $^{18}$;

5) renewal of court panel and lack of necessary practice for young judges ${ }^{19}$;

6) a court ruling on the case based on the normative act that is afterwards recognised unconstitutional ${ }^{20}$, etc.

E.V. Vaskovskyy, when analysing causes of judicial errors, wrote that regardless of how well the judges are trained and how justly and carefully they carry out their duties, there is still no guarantee of prevention of judicial misconducts or errors. Not only inaccurate understanding of the law or occasional carelessness when identifying the factual circumstances in the case, but also subjective opinions, preferences, likings or dislikings of the judges, as well as the influence of local opinions can be the causes of erroneous rulings. The author insists that conscious evasion of justice, due to granted by the court freedom of opinion, falls out of close inspection and remains unpunished. One of the methods for protection against such misconducts by the judges is the possibility of repeated consideration of the case. However, in his opinion, this is not enough not only because the second court that reviews the cases can also make errors or violate law regulations, but also because each legislation, regardless of how perfect it is, contains gaps, ambiguities and contradictions. Consequently, the differences in understanding and application of the law can occur not only between individuals, but also between the judges. One court interprets the law in one way, the other in another way and the third yet differently from the other two. The absence of uniformity in judicial practice destroys the unity of the state law, weakens the force of law and undermines the principle of equality of citizens before the law ${ }^{21}$.

According to A.S. Grytsanov, there are objective reasons for errors in judicial practice. Those are some imperfections in procedural institutions, complexity and a significant amount of legislation that is applicable in civil cases, gaps in the substantive

mosti sudebnoj vlasti. (Izlozhenie doklada Predsedatelja Vysshego Arbitrazhnogo Suda Rossijskoj Federacii V. F. Jakovleva) [From Reforming to Improvement of Judicial-arbitrary System, Strengthening the Independence of Judiciary. (Presentation of the report of the Chairman of the Supreme Arbitration Court of the Russian Federation by V.F. Yakovlev)]. Vestnik Vysshego Arbitrazhnogo Suda Rossijskoj Federacii [Bulletin of the Supreme Arbitration Court of the Russian Federation]. 1998, 4: 5-20.

18 Topil'skaja, L. Kak nam obustroit' sudebnuju vlast' [Topilskaya, L. How We Should Organize Our Judiciary]. Rossijskaja justicija [Russian Justice]. 2000, 11: 13-15.

19 Lebedev, V. Rasshirenie dostupa k pravosudiju - odna iz celej sudebnoj reformy [Lebedev, V. Improving Availability of Justice - One of the Goals of Judicial Reform]. Rossijskaja justicija [Russian Justice]. 1999, 9: 2-4.

20 Anishina, V. Primenenie postanovlenij Konstitucionnogo Suda RF sudami obshhej jurisdikcii [Anishyna, V. Application of Constitutional Court of RF Resolutions by the Courts of General Jurisdiction]. Rossijskaja justicija [Russian Justice]. 1999, 11: 2-5.

21 Vas'kovskij, E. V. Uchebnik grazhdanskogo processa. Izd. 2-e, pererabotannoe [Vaskovskyy, E.V. Textbook of Civil Process. 2nd ed., revised]. Moskva: Br. Bashmakovy, 1917, p. 33. 
law, as well as working conditions of judges and other court officials. The author splits all errors into two categories: those that are not connected with the individual judge (objective) and subjective causes. A.S. Grytsanov includes the following errors in the first group: preparation before case consideration, quality of court consideration, improvement of physical laws and working conditions of judges. The second group includes legal and professional training of judges, his/her professional qualities, the level of justice and the general cultural level, psychological preparation ${ }^{22}$.

G.A. Zhylin, when exploring the issue of judicial errors, has noted that many courts exhibit a rather careless attitude to compliance with procedural regulations. Supreme Court judges are no exception in this case, as they often do not highlight procedural violations in resolutions when the court ruling is cancelled due to erroneous usage of substantive law regulations ${ }^{23}$.

I.M. Zaitsev thinks that those authors, who highlight the objective reasoning behind judicial errors, in essence defend the absence of judge's guilt in the errors' occurrence. In his opinion, the objectification of the causes of judicial errors is theoretically irrelevant and practically harmful. It can lead to the recognition of the inevitability of those errors. Such approach is consequently only one step away from the recognition of the "right for a judicial error". The court can and should prevent any kind of errors, and if it so happens that those errors occur, it has all the means for their correction in a timely and most efficient manner. It cannot be forgotten that judicial errors are unlawful. That is why they cannot have any social basis. Each error that occurred is an evidence of procedural misconduct, ignorance of some of the procedural methods that are available to the court ${ }^{24}$.

The above mentioned author considers the personality of the judge to be the main cause of judicial errors. Thus, he regards judicial errors as predominantly subjective. They occur in procedural operations of court officials, where people are always guilty as they were not able or willing to apply/follow all the law regulations in the scope of consideration of a particular case or issue. Any specific error is easily justified by subjective reasons connected to the judge's personality. All other factors are also influencing the occurrence of errors, however, their role is so minimal that they can be either disregarded in practical outlook or simply included in the list of error causes.

22 Gricanov, A. S. Kassacionnoe proizvodstvo v sovetskom grazhdanskom processe [Gritsanov, A.S. The Appeal Proceedings in the Soviet Civil Process]. Tomsk: Izd. Tomskogo un-ta, 1980, p. 129.

23 Zhilin, G. A. Zashhita prav cheloveka v grazhdanskom sudoproizvodstve [Zhylin, G.A. Protection of Human Rights in Civil Proceedings]. Rossijskaja justicija [Russian Justice]. 1998, 1: 5-7.

24 Zajcev, I. M. Teoreticheskie voprosy ustranenija sudebnyh oshibok $v$ grazhdanskom processe. Dis. d-ra jurid. nauk [Zaitsev, I.M. Theoretical Questions on Judicial Errors Elimination in Civil Proceedings. Dis. PhD legal sciences]. Saratov, 1986, p. 65. 
The opinion of K.R. Mursalimova should be noted particularly, as in the scope of his research on law enforcement errors he has come up with the conclusion that origins of law enforcement errors in most cases lie in the defects of consciousness of the subject of law enforcement, his/her professional and moral levels, meaning that the origins of errors lie in the defects of personality, in their subjective (psychological) $\operatorname{area}^{25}$.

In the present paper author's opinion, the causes of judicial errors include the following:

1) inadequate level of education and training of judges;

2) lack of appropriate moral qualities of judges;

3) lack of knowledge of substantive and procedural law;

4) dishonesty, superficial, careless and formal attitude of judges towards their duties;

5) inability to organize their work correctly;

6) careless filing of procedural documents;

7) absence of job experience;

8) ignorance of higher court clarifications on the application of state law;

9) subjective views, likes and dislikes of judges;

10) low level of judges' discipline;

11) the bias of the court;

12) violation of statutory procedural terms, etc.

To prevent a judicial error in a civil litigation means to not let it occur in the process of rendering justice during the civil proceeding. Multiple aspects to a judicial error, as well as the variety of its causes lead to creation of various methods for judicial error prevention.

Thus, methods aimed at prevention of judicial errors could be theoretically split into 2 groups: procedural and nonprocedural, based on whether the corresponding method is within the scope of the Civil Procedure Law or not. The methods in the second group (nonprocedural) include the following ones: training of judges; improving candidate selection for the judge positions; improving the institute of disciplinary responsibility of the judge for judicial errors; systematic learning and analysis of judicial practice, court operations improvement, increasing the amount of stuff judges, etc.

Procedural methods for judicial errors prevention in civil litigation are a specific type of legal procedural methods. Despite the fact that the term "procedural methods" is widely used in legal literature, the official definition of legal procedural methods does not exist in jurisprudence. Thus, some authors define legal procedural methods 
as legal tools and actions that support the interests of subjects of the judicial process ${ }^{26}$. Other authors define legal procedural methods as legal instruments that help to activate the judicial mechanism for protection of subjective rights of different origins and types of violation ${ }^{27}$. According to Y.A. Popova, procedural methods are a set of specific forms, methods, principles, institutions of procedural law, which support the right to judicial protection ${ }^{28}$. N.N. Efremova reckons that legal procedural methods are legal instruments that support the interests of businesses and proper functioning of the protection mechanism of the rights and legal interests of the participants of the legal process and this is how proceedings are carried out ${ }^{29}$.

It is important to note that the existing Civil Procedure Law is not effective in prevention of judicial errors occurrence. Finding a resolution to an issue of prevention of judicial errors in civil litigation is tightly connected with further improvement of the Civil Procedure Law. One of the missions of civil procedure studies is to workout scientifically justified recommendations that would help the legislator to further correct the civil procedure form in a way as to minimise the amount of judicial errors.

Considering all of the above mentioned, the procedural methods of judicial errors prevention in civil litigation stand for specific provisions of the Civil Procedure Law that once executed would fundamentally hinder the occurrence of judicial errors during case proceedings and the rendering of the ruling.

The variety of procedural methods for prevention of judicial errors in civil litigation is very broad: most procedural norms and institutes can be regarded as kinds of procedural methods for judicial error prevention. Therefore, scientific

26 Strunkov, S. K. Processual'no-pravovye sredstva: problemy teorii i praktiki. Pod red. A. V. Mal'ko [Strunkov, S.K. Legal Procedural Methods: Issues in Theory and Practice. Edited by A.V. Malko]. Saratov: Izd-vo GOU VPO "Saratovskaja gosudarstvennaja akademija prava", 2005, p. 28; Lapshinov, Je. V. Ponjatie pravovyh sredstv v pravovoj tradicii [Lapshynov, E.V. Understanding of the Legal Methods in the Legal Tradition]. Leningradskij juridicheskij zhurnal [Leningrad Legal Journal]. 2009, 3(17): 173-186.

27 Kolesov, P. P. K razvitiju uchenija o processual'nyh sredstvah zashhity prava i ob iske [Kolesov, P.P. The Development of Procedural Means of Protection of the Right for a Proceeding]. Zametki o sovremennom grazhdanskom i arbitrazhnom processual'nom prave. Pod red. M. K. Treushnikova [Notes on Current Civil Procedural Law and Arbitration. Edited by M.K. Treushnikova]. Moskva: OAO “Izdatel'skij dom “Gorodec”", 2004, p. 132.

28 Popova, Ju. A. Processual'nye sredstva zashhiti chastnopravovogo interesa v sudoproizvodstve iz publichno-pravovyh otnoshenij [Popova, Y.A. Procedural Methods for Prevention of Private Legal Interests in Litigation of Public Legal Relations]. Teoreticheskie i prikladnye problemy reformy grazhdanskoj jurisdikcii [Theoretic and Applied Problems of the Reform of Civil Jurisprudence]. Ekaterinburg, 1998, p. 112.

29 Efremova, N. N. Processual'nye sredstva obespechenija dostupnosti pravosudija $v$ sfere predprinimatel'skoj i inoj jekonomicheskoj dejatel'nosti ( $v$ kontekste mezhdunarodno-pravovyh standartov). Avtoref. dis. ... kand. jurid. nauk [Efremova, N.N Procedural Means of Ensuring Justice in the Sphere of Entrepreneurial and Other Economic Activities (in the Context of International Law Standards). Autoref. dis. ... cand. jud. studies]. Saratov, 2005, p. 8. 
classification of procedural methods for judicial error prevention in civil proceedings has an important theoretic and practical meaning.

Based on their nature, procedural methods could be divided into:

1) obligatory;

2) optional.

Obligatory procedural methods are established in the Civil Procedure Law through imperative norms and are used in each proceeding. The institute of case proceedings before trial is one of such methods. Optional procedural methods of judicial errors prevention are carried out through discretionary norms of procedural law and are normally applied upon the request of individuals that take part in the case. For example, according to part 2 of Article 169 of the CPC of Ukraine, upon the request of one of the parties and considering the circumstances of the case, the court can postpone a legal investigation due to failure of the representative to show up at the proceeding for a reputable reason ${ }^{30}$.

Depending on the subject of use, procedural methods of judicial errors prevention in civil proceedings can be split into 3 groups:

1) procedural methods used by the court;

2) procedural methods used by individuals that are taking part in the case;

3) procedural methods that are used by other participants of the civil process.

One of the procedural methods of judicial errors prevention that are used by the court is the provisions in paragraph 4, part 1 of Article 201 of the CPC of Ukraine, stating that the court is obliged to suspend the proceeding on the case if it cannot be investigated until the other case is resolved, that is reviewed within the scope of constitutional, civil, domestic, criminal or administrative litigation ${ }^{31}$.

One of the procedural methods of judicial errors prevention that are used by individuals that take part in the case are the norms that establish the right to appeal court decisions, which incentivises the judge to render a legal and justified verdict, the right to recast judges and others.

The institute of representation in civil litigation should be referred to procedural methods for judicial error prevention that are used by other parties of the civil process. For instance, an individual that provides legal assistance, whilst carrying out his duties helps the court to identify significant circumstances in the case and thereby helps to prevent judicial errors.

30 Cyvil'nyj procesual'nyj kodeks Ukrai'ny [Civil Procedure Code of Ukraine]. Ukraine, 2004, No. 1618-IV [interactive]. [accessed on 2014-01-11]. <http://zakon1.rada.gov.ua/laws/ show/1618-15>.

31 Cyvil'nyj procesual'nyj kodeks Ukrai'ny [Civil Procedure Code of Ukraine]. Ukraine, 2004, No. 1618-IV [interactive]. [accessed on 2014-01-11]. <http://zakon1.rada.gov.ua/laws/show/1618$15>$. 
As for the description of individual procedural methods of judicial errors prevention in civil litigation, they include provisions in Article 3 of the CPC of Ukraine that support the rights for recusal of judges.

The right to recuse judges is an important guarantee of independence, objectivity and impartiality of the court and thus serves as a guarantee of the accuracy of its operations.

According to the existing Civil Procedure Law (part 1 of Article 20 of the CPC of Ukraine), the judge cannot participate in the case proceeding and is subject to recusal (self-recusal) if:

1) during a previous proceeding on the case he took part in the process as a witness, expert, specialist, translator, representative, secretary of the court proceeding;

2) he has a direct or indirect personal interest in the outcome of the court proceeding;

3) he is a member of the family or is closely related (husband, wife, father, mother, stepfather, stepmother, son, daughter, stepson, stepdaughter, brother, sister, grandfather, grandmother, grandson, granddaughter, adopting or adopted parent, guardian or carer, family member or a close relative of those individuals);

4) there are other circumstances that can cast doubt on the objectivity and impartiality of the judge;

5) the order of judge selection was not carried out correctly, as per part 3 of Article 11 of the CPC of Ukraine ${ }^{32}$.

The provisions of Article 159 of the CPC of Ukraine are also aimed at prevention of judicial errors. Thus, in part 1 of the above mentioned Article, it is stated that the court should directly examine the evidence in the case during the proceeding ${ }^{33}$. This provision helps the judge to make a decision on the accuracy of presented facts.

A.F. Voronov was right when he claimed that technical progress that triggered the global expansion of video recording technology and development in networking will result in the increase of exceptions from principles of verbalness and directness of court proceeding, "up to the point where court proceedings are carried out in the form of internet or teleconferences without mandatory physical presence of proceeding parties in court" 34 . Thus, the Law of Ukraine "On Amendments to certain legislative acts of Ukraine as to participation in the court proceeding through the

32 Ibid.

33 Cyvil'nyj procesual'nyj kodeks Ukrai'ny [Civil Procedure Code of Ukraine]. Ukraine, 2004, No. 1618-IV [interactive]. [accessed on 2014-01-11]. <http://zakon1.rada.gov.ua/laws/show/1618$15>$.

34 Voronov, A. F. Jevoljucija funkcional'nyh principov grazhdanskogo processa. Avtoref. dis. ... d-ra jurid. nauk [Voronov, A.F. The Evolution of Functional Principles of the Civil Process. Autoref. dis.... of leg. studies PhD]. Moskva, 2009, p. 10-11. 
means of video conferencing" No. 5041-VI from 04.07.2012 $2^{35}$ was supplemented with Article 158 of the CPC of Ukraine "Taking part in court proceeding through a videoconference", which states that the court can approve participation in the proceeding through the videoconference upon its own initiative or in response to the request of the proceeding party or other member of the civil process ${ }^{36}$. However, there is no doubt in significance of direct involvement principle in the court proceeding in both educational and practical application of judicial error prevention.

It has been stated many times in the procedural literature that the hierarchy of court systems helps to prevent judicial error occurrence ${ }^{37}$. The opinion that hierarchy in the court system is one of the methods of judicial error prevention is justified by the following arguments: firstly, the judge that renders a decision knows that his conclusions on the case can be revised in higher court ${ }^{38}$, which makes the judge handle the legal proceeding in a more responsible way; secondly, the rulings of higher courts (especially the Supreme Court of Ukraine) direct lower courts at the accurate investigation and resolution of similar civil proceedings; thirdly, the operations of higher courts on checking the accuracy of lower courts verdicts helps to identify and analyse judicial errors typical for lower courts, which helps to build a compilation of court practices that are further on presented to lower courts as guidance for accurate and fair application of law.

More so, one of the procedural methods of judicial error prevention is a procedural norm that constitutes that court resolutions should be made in the jury room, where no one except for the court staff involved in the decision making is allowed to be present. (Articles 195, 196 of the CPC of Ukraine) ${ }^{39}$. First of all, the principle of privacy of the jury room allows the judge to analyse the norms of law in

35 Pro vnesennja zmin do dejakyh zakonodavchyh aktiv Ukrai'ny shhodo uchasti u sudovomu zasidanni v rezhymi videokonferencii': Zakon Ukrai'ny [On Amendments to Specific Legislative Acts of Ukraine in Regards to Participation in the Court Case in a Videoconference Mode: The Law of Ukraine]. Ukraine, 2012, No. 5041-VI [interactive]. [accessed on 2014-0111]. <http://zakon1.rada.gov.ua/laws/show/5041-17/paran24\#n24>.

36 Cyvil'nyj procesual'nyj kodeks Ukrai'ny [Civil Procedure Code of Ukraine]. Ukraine, 2004, No. 1618-IV [interactive]. [accessed on 2014-01-11]. <http://zakon1.rada.gov.ua/laws/show/1618$15>$.

37 Cyvil'nyj proces Ukrai'ny: akademichnyj kurs: pidruchnyk dlja stud. juryd. spec. vyshh. navch. zakl.; za red. S.Ja. Fursy [The Civil Procedure Code of Ukraine: Academic Course: Textbook for Stud. of Spec. Leg. Higher Edu. Inst.; edited by S.Y. Fursa]. Kyi'v: Vydavec' Fursa S.Ja.: KNT, 2009, p. 714, 744; Komarov, V. V.; Bigun, V. A.; Barankova, V. V., et al. Kurs cyvil'nogo procesu : pidruchnyk; za red. V. V. Komarova [Komarov, V. V.; Bigun, V. A.; Barankova, V. V., et al. The Course on Civil Process: Textbook; edited by V.V. Komarova]. Xarkiv: Pravo, 2011, p. 822.

38 Mihajlovskaja, I. B. Sudy i sud'i: nezavisimost' i upravljaemost' [Mikhailovska, I.B. Courts and Judges: Independence and Management]. Moskva: Prospekt, 2008, p. 116.

39 Cyvil'nyj procesual'nyj kodeks Ukrai'ny [Civil Procedure Code of Ukraine]. Ukraine, 2004, No. 1618-IV [interactive]. [accessed on 2014-01-11]. <http://zakon1.rada.gov.ua/laws/show/1618$15>$. 
a calm surrounding and examine the presented evidence once more, thus avoiding judicial errors. Secondly, the principle prevents individuals that have a personal interest in the case outcome from influencing the lawfulness of the verdict.

Some authors name the principle of competition as a preventive method of judicial error occurrence. Thus, according to the American lawyer W. Bernham, an accurate verdict is a result of the clash of two opposing opinions. The author supports his point of view by saying that unconsciously the judge can be inclined towards a certain decision, based on the presented information when the whole picture is not yet clear. The danger of such early conclusions is that the judge becomes somehow involved in those. The principle of competition, in his opinion, allows seeing the factual and evidence material and is the only means of avoiding early and erroneous conclusions of the judge on the case, as it allows the parties to make and present conclusions themselves based on their evidence. More so, according to W. Bernham, the principle of competition allows the judge to get a lot more information. Since the information is presented in pieces rather than sequentially, it frees the judge from previous conclusions ${ }^{40}$. V.V. Samsonov mentions that one of the advantages of the principle of competition is that each party in an attempt to win the process tries to present all the facts/evidence to the court that lead to their advantage and undermine the claims of the other party, which allows the court to study the case materials in greater depth ${ }^{41}$.

One of the most effective methods of judicial error prevention in the civil litigation is a collegiate civil court.

E.V. Vaskovskyy thought that a collegiate proceeding of civil cases is one of the main guarantees of impartial and accurate ways to render justice. In his view, collegiate litigation of cases has the following advantages:

1. Collegiate proceeding provides for a more detailed and multi-dimensional discussion.

2. Whilst improving the quality of certain court decisions, the collegiate proceeding of cases provides for a more impartial handling of the case. It is easier to pressure, bribe or influence a single judge than a panel of judges. In the collegiate panel members are ashamed of each other, afraid to let each other down and are afraid of attracting publicity to some indiscreet actions. Even if it is possible to influence one or a couple of panel members, the others will retain impartiality and will provide the necessary counteraction to those that are willing to act indiscreetly.

40 Burnham, W. Introduction to the Law and Legal System of the United States. .: West Publishing Co., 1995, p. 78.

41 Samsonov, V. V. Sostjazatel'nost' v sisteme grazhdanskih processual'nyh principov [Samsonov, V.V. Competitiveness in the System of Civil Procedure Principles]. Vestnik Saratovskoj gosudarstvennoj akademii prava [Bulletin of Saratov National Law Academy]. 1998, 1: 53-65. 
3. During the court proceeding, each judge of the collegiate panel who understands that his responsibility is shared with the jury feels more independent and acts more freely, compared to cases when he/she has to render the decision himself/herself.

4. The verdict of the collegiate panel, being the result of collective work of several judges, is ranked higher than decisions of individual judges ${ }^{42}$.

The existing Civil Procedure Law provides for collegiate consideration of all civil proceedings in the Court of Appeal, the Court of Cassation and the Supreme Court of Ukraine. In courts of first instance only certain civil proceedings are carried out by a collegiate panel, composed of one judge and two judicial assessors that are entitled to all the rights of the judge (Article 18 of the CPC of Ukraine), when rendering justice. Those include cases of special proceeding that focus on:

- $\quad$ restricting the civil capacity of an individual, recognition of an individual being not self-sufficient and renewal of sufficiency of an individual;

- recognition of an individual as lost or dead;

- adoption;

- $\quad$ provision of mandatory mental health care;

- mandatory hospitalization to TB facilities (Article 234 of the CPC of Ukraine $)^{43}$.

Despite supporting the viewpoint that consideration of civil proceedings by a single judge increases the risk of judicial error occurrence, it is also still considered that the meaning of collegiate panel addressing the case should not be overstated, as collegiate panel case proceeding also has a number of disadvantages.

First of all, it is important to note that when making collegiate decisions, an essential role is played by social and psychological aspects of interpersonal, group interaction, where conformity is prioritized. Conformity is the tendency of a person to change his/her opinion under group pressure, a conscious submission of a person to the opinion of the group in order to avoid conflict ${ }^{44}$.

Any judge, being a member of the collegiate court, cannot be completely spared from the influence of other colleagues. A striking proof of conformity within panels of judges is the fact that most cancelled erroneous decisions of the Court of Appeal and the Court of Cassation are mostly adopted unanimously, rather than as a result of a majority vote.

42 Vas'kovskij, E. V. Uchebnik grazhdanskogo processa. MGU im. M. V. Lomonosova, jurid. fak., kaf. grazhdan. processa. - KubGU, jurid. fak., kaf. grazhdan. processa i trudovogo prava [Vaskovskyy, E.V. Civil Process Tutorial. M.V. Lomonosov MSU, Legal faculty, dep. of civil procedure. - KubSU, Legal. fac. dep. of civil procedure and Labor Law]. Krasnodar, 2003, p. 52-53.

43 Cyvil'nyj procesual'nyj kodeks Ukrai'ny [Civil Procedure Code of Ukraine]. Ukraine, 2004, No. 1618-IV [interactive]. [accessed on 2014-01-11]. <http://zakon1.rada.gov.ua/laws/show/1618-15>.

44 Stoljarenko, L. D. Psihologija: Uchebnik dlja vuzov [Stolyarenko, L.D. Psychology: Textbook for Universities]. Piter, 2008, p. 464. 
Apart from conformity, judicial errors in the jury court proceedings are often caused by the desire of individual judges to put less effort into achieving the norms mentioned in Article 1 of the CPC of Ukraine, compared to the verdicts by a single judge. In psychology, this occurrence is called social laziness ${ }^{45}$. It is supported by the reasoning that during collegiate decision-making an individual judge is not fully accountable for the end decision. Every judge knows that in case a judicial error occurs, the responsibility is shared by the panel, instead of him carrying an individual responsibility.

The other aspect that significantly affects the ability of collegiate court to render accurate error-free verdicts is group thinking. The latter is a mode of thinking that evolves when the desire to reach a compromise in the group overrides the realistic assessment of possible alternatives ${ }^{46}$.

According to many scientists, the best way to improve the quality of civil justice and maintain just, impartial trials is to promote transparency of the actions and decisions of the judges. A.B. Lysyutkin notes that publicity of any professional legal practice is a prerequisite for prevention of possible judicial errors by the subjects of law ${ }^{47}$. S.V. Praskova states that transparency in the justice system reduces the likelihood of judicial error occurrence, guarantees the independence of the court and promotes its credibility in public and within other branches of the government ${ }^{48}$. The fact that transparency in justice is a preventive method for judicial error occurrence is also supported by V.M. Lebedev, who states that openness and transparency is one of the main hurdles to all negative occurrences ${ }^{49}$.

Understanding the significance of transparency in justice in Ukraine has led to the adoption of the Law of Ukraine "On Access to Court Decisions" in 2005 $5^{50}$. This law

45 Majers, D. Psihologija / D. Majers; perevod s angl. I. A. Karpikov, V. A. Starovojtova. 2-e izd. [Mayers, D. Psychology / D. Mayers; translation from English by I. A. Karpikov, V.A. Starovoytova. 2nd edition]. Mn.: Popurrm, 2006, p. 757.

46 Ibid., p. 758; Svencickij, A. L. Social'naja psihologija: Uchebnik [Sventsisky, A.L. Social Psychology: Textbook]. Moskva: TK Velbi, Izd-vo Prospekt, 2004, p. 214-217.

47 Lisjutkin, A. B. Juridicheskoe znachenie kategorii «oshibka»: teoretiko-metodologicheskij aspekt [Lisutkin, A.B. The Legal Meaning of the "Error" Category: Theoretical Methodological Aspect]. Saratov: SGAP, 2001, p. 334-335.

48 Praskova, S. V. Teoreticheskie osnovy glasnosti pravosudija. Avtoref. dis. ... kand. jurid. nauk [Praskova, S.V. Theoretic Basis of Transparency of Jurisdiction. Autoref. dis. ... cand. of Legal Studies]. Moskva, 2004, p. 3.

49 Nachalo rabochej vstrechi s Predsedatelem Verhovnogo Suda Vjacheslavom Lebedevym: ofic. sajt Prezidenta RF [Beginning of a Working Session with the Representative of Supreme Court Vyacheslav Lebedev: Official Website of the President of Russian Federation]. Russia, 2006 [interactive]. [accessed on 2014-01-11]. <http://www.kremlin.ru/appears/2006/11/03/1848_ type63378_113391.shtml>.

50 Pro dostup do sudovyh rishen': Zakon Ukrai'ny [On Access to Court Rulings: The Law of Ukraine]. Ukraine, 2005, No. 3262-IV [interactive]. [accessed on 2014-01-11]. <http://zakon4. rada.gov.ua/laws/show/3262-15>. 
defines the procedure of access to court rulings, in order to ensure the transparency of the general jurisdiction court operations, predictability of court decisions and promotion of fair application of law. More so, the adoption of this law has a positive effect on the functioning of the courts and consequently the whole judicial system as it objectively increases the liability of judges for the quality of their work.

In the present paper author's opinion, a particularly effective form of influence on the reasons and conditions of judicial errors in civil proceedings are compilations of judicial practices that are issued by higher courts. They include judicial practice on application of the existing civil law in different categories of civil litigations. They reflect the efficiency of the use of law in Ukrainian courts. The courts of first instance should study judicial practice to understand the content of Civil Law and ensure its accurate and equal usage. Compilations of court decisions made by higher courts should be taken into consideration by the legislator in the process of improvement of existing legislation and the publication of new normative acts.

\section{Conclusions}

After analysing the procedural and legal nature of a judicial error, the author of this paper suggests the below definition of this notion. A judicial error is an unlawful act (inaction) of the authorized entity (the judge), occurring regardless of his intention, outlined in a specific procedural document, that violates the procedural and (or) substantive laws, results in a failure to achieve the goals and carry out the duties of the procedural litigation, as a result of which a specific court ruling can be vitiated or modified either by a higher court or by the issued court (correction of typographical and arithmetic errors, additional ruling, judgement clarification).

As causes of judicial errors, the author of the paper suggests taking the following ones: 1) inadequate level of education and training of judges; 2) lack of appropriate moral qualities of judges; 3 ) lack of knowledge of substantive and procedural law; 4) dishonesty, superficial, careless and formal attitude of judges towards their duties; 5) inability to organize their work correctly; 6) careless filing of procedural documents; 7) absence of job experience; 8) ignorance of higher court clarifications on the application of state law; 9) subjective views, likes and dislikes of judges; 10) low level of judges' discipline; 11) the bias of the court; 12) violation of statutory procedural terms, etc.

Having examined the procedural methods of judicial errors prevention in civil proceedings, the author thinks that those methods are certain provisions of the civil procedure law, the execution of which would prevent the occurrence of judicial errors and civil court resolutions substantially.

One of the most effective methods of increasing the effectiveness of justice system in civil proceedings includes the following: 
- the right to recast judges;

- consideration of cases by a panel of judges;

- rendering a ruling in the jury room;

- institutional structure of the court system;

- the concept of direct court investigation;

- transparency and openness of the justice system;

- compilations of judicial practice by higher courts.

\section{References}

Anishina, V. Primenenie postanovlenij Konstitucionnogo Suda RF sudami obshhej jurisdikcii [Anishyna, V. Application of Constitutional Court of RF Resolutions by the Courts of General Jurisdiction]. Rossijskaja justicija [Russian Justice]. 1999, 11: 2-5.

Burnham, W. Introduction to the Law and Legal System of the United States. : West Publishing Co., 1995.

Cyvil'nyj proces Ukrai'ny: akademichnyj kurs: pidruchnyk dlja stud. juryd. spec. vyshh. navch. zakl.; za red. S.Ja. Fursy [The Civil Procedure Code of Ukraine: Academic Course: Textbook for Stud. of Spec. Leg. Higher Edu. Inst.; edited by S.Y. Fursa]. Kyi'v: Vydavec' Fursa S.Ja.: KNT, 2009.

Cyvil'nyj procesual'nyj kodeks Ukrai'ny [Civil Procedure Code of Ukraine]. Ukraine, 2004, No. 1618-IV [interactive]. [accessed on 2014-0111]. <http://zakon1.rada.gov.ua/laws/ show/1618-15>.

Efremova, N. N. Processual'nye sredstva obespechenija dostupnosti pravosudija $v$ sfere predprinimatel'skoj $i$ inoj jekonomicheskoj dejatel'nosti (v kontekste mezhdunarodno- pravovyh standartov). Avtoref. dis. ... kand. jurid. nauk [Efremova, N.N Procedural Means of Ensuring Justice in the Sphere of Entrepreneurial and Other Economic Activities (in the Context of International Law Standards). Autoref. dis. ... cand. jud. studies]. Saratov, 2005.

Gricanov, A. S. Kassacionnoe proizvodstvo $v$ sovetskom grazhdanskom processe [Gritsanov, A.S. The Appeal Proceedings in the Soviet Civil Process]. Tomsk: Izd. Tomskogo unta, 1980.

Kolesov, P. P. K razvitiju uchenija o processual'nyh sredstvah zashhity prava i ob iske [Kolesov, P.P. The Development of Procedural Means of Protection of the Right for a Proceeding]. Zametki o sovremennom grazhdanskom i arbitrazhnom processual'nom prave. Pod red. M. K. Treushnikova [Notes on Current Civil Procedural Law and Arbitration. Ed. By M.K. Treushnikova]. Moskva: OAO "Izdatel'skij dom "Gorodec", 2004.

Komarov, V. V.; Bigun, A. A.; Barankova, V. V., et al. Kurs cyvil'nogo procesu: pidruchnyk; za red. V. V. Komarova 
[Komarov, V. V.; Bigun, A. A.; Barankova, V. V., et al. The Course on Civil Process: Textbook; edited by V.V. Komarova]. Xarkiv: Pravo, 2011. Konstytucija Ukrai'ny [Constitution of Ukraine]. Ukraine, 1996, No. 245k/96-VR [interactive]. [accessed on 2014-01-11]. <http://zakon0.rada. gov.ua/laws/show/254\%D0\%BA/96\%D0\%B2\%D1\%80>.

Lapshinov, Je. V. Ponjatie pravovyh sredstv v pravovoj tradicii [Lapshynov, E.V. Understanding of the Legal Methods in the Legal Tradition]. Leningradskij juridicheskij zhurnal [Leningrad Legal Journal]. 2009, 3(17): 173-186.

Lebedev, V. Ot koncepcii sudebnoj reformy $\mathrm{k}$ novym idejam razvitija sudebnoj sistemy [Lebedev, V. From The Concept of Judicial Reform to New Ideas on Development of the Judicial System]. Rossijskaja justicija [Russian justice]. 2000, 3: 2-5.

Lebedev, V. Rasshirenie dostupa k pravosudiju - odna iz celej sudebnoj reformy [Lebedev, V. Improving Availability of Justice - One of the Goals of Judicial Reform]. Rossijskaja justicija [Russian justice]. 1999, 9: 2-4.

Leont'ev, E. V. Oshibka sud'i v mehanizme realizacii norm grazhdanskogo processual'nogo prava [Leontiev, E.V. Judicial Error in the Mechanism of Civil Procedure Law Enforcement]. Materialy nauch.-prakt. konf., posvjashhennoj 80-letiju professora M. A. Vikut; otv. red N.V. Kuznecov [Sicent. Pract. Conf. Materials, Dedicated to 80th Anniversary of Professor M.A.Vykut; edited by N.V. Kusnetsov]. Saratov: Izdatel'stvo GOU VPO "Saratovskaja gosudarstvennaja akademija prava", 2003.

Leont'ev, E. V. Sudebnaja oshibka v grazhdanskom processe: Ponjatie i harakternye cherty [Leontiev, E.V. Judicial Error in the Civil Process: Concept and Characteristics]. Sbornik "Sovremennye problemy grazhdanskogo prava i processa" [Collection "Current Issues in Civil Procedure Law”]. Novosibirsk, 2002: 186-189.

Lisjutkin, A. B. Juridicheskoe znachenie kategorii "oshibka": teoretikometodologicheskij aspekt [Lisutkin, A.B. The Legal Meaning of the "Error" Category: Theoretical Methodological Aspect]. Saratov: SGAP, 2001.

Majers, D. Psihologija. D. Majers; perevod s angl. I. A. Karpikov, V. A. Starovojtova. - 2-e izd. [Mayers, D. Psychology. D. Mayers; translation from English by I. A. Karpikov, V.A. Starovoytova. 2nd edition]. Mn.: Popurrm, 2006.

Mihajlovskaja, I. B. Sudy i sud'i: nezavisimost' i upravljaemost' [Mikhailovska, I.B. Courts and Judges: Independence and Management]. Moskva: Prospekt, 2008.

Mursalimov, K. R. Pravoprimenitel'nye oshibki. Diss. kand. jur. nauk [Mursalimov, K.R. Law Enforcement Errors. Diss. cand. legal sciences]. Nizhnij Novgorod, 2000.

Nachalo rabochejvstrechis Predsedatelem Verhovnogo Suda Vjacheslavom Lebedevym: ofic. sajt Prezidenta RF [Beginning of a Working Session with the Representative of Supreme Court Vyacheslav Lebedev: Official Website of the President of Russian Federation]. Russia, 2006 
[interactive]. [accessed on 2014-0111]. <http://www.kremlin.ru/appears/ 2006/11/03/1848_type633 78_113391. shtml $>$.

Ot reformirovanija k sovershenstvovaniju sudebno-arbitrazhnoj sistemy, ukrepleniju nezavisimosti sudebnoj vlasti. (Izlozhenie doklada Predsedatelja Vysshego Arbitrazhnogo Suda Rossijskoj Federacii V. F. Jakovleva) [From Reforming to Improvement of Judicial-arbitrary System, Strengthening the Independence of Judiciary. (Presentation of the Report of the Chairman of the Supreme Arbitration Court of the Russian Federation by V. F. Yakovlev)]. Vestnik Vysshego Arbitrazhnogo Suda Rossijskoj Federacii [Bulletin of the Supreme Arbitration Court of the Russian Federation]. 1998, 4: 5-20.

Popova, Ju. A. Processual'nye sredstva zashhiti chastnopravovogo interesa v sudoproizvodstve iz publichnopravovyh otnoshenij [Popova, Y.A. Procedural Methods for Prevention of Private Legal Interests in Litigation of Public Legal Relations]. Teoreticheskie $i$ prikladnye problemy reformy grazhdanskoj jurisdikcii [Theoretic and Applied Problems of the Reform of Civil Jurisprudence]. Ekaterinburg, 1998.

Praskova, S. V. Teoreticheskie osnovy glasnosti pravosudija. Avtoref. dis. ... kand. jurid. nauk [Praskova, S.V. Theoretic Basis of Transparency of Jurisdiction. Autoref. dis. ... cand. of Legal Studies]. Moskva, 2004.

Pro dostup do sudovyh rishen': Zakon Ukrai'ny [On Access to Court Rulings: The Law of Ukraine]. Ukraine, 2005, No. 3262-IV [interactive]. [accessed on 2014-01-11]. <http://zakon4.rada. gov.ua/laws/show/3262-15>.

Pro vnesennja zmin do dejakyh zakonodavchyh aktiv Ukrai'ny shhodo uchasti u sudovomu zasidanni $\mathrm{v}$ rezhymi videokonferencii': Zakon Ukrai'ny [On Amendments to Specific Legislative Acts of Ukraine in Regards to Participation in the Court Case in a Videoconference Mode: The Law of Ukraine]. Ukraine, 2012, No. 5041-VI [interactive]. [accessed on 2014-0111]. <http://zakon1.rada.gov.ua/laws/ show/5041-17/paran24\#n24>.

Rudenko, Ju. M. Dejatel'nost' advokata po preduprezhdeniju, vyjavleniju $i$ ispravleniju sudebnyh oshibok $v$ grazhdanskom sudoproizvodstve (organizacionno-pravovoj aspekt). Diss. ... kand. jurid. nauk [Rudenko, Y.M. The Actions of a Lawyer on Prevention, Identification and Correction of Judicial Errors in Civil Proceedings (Organizational-legal Aspect). Diss. cand. legal sciences]. Moskva, 2009.

Samsonov, V. V. Sostjazatel'nost' V sisteme grazhdanskih processual'nyh principov [Samsonov, V.V. Competitiveness in the System of Civil Procedure Principles]. Vestnik Saratovskoj gosudarstvennoj akademii prava [Bulletin of Saratov National Law Academy]. 1998, 1: 53-65.

Stoljarenko, L. D. Psihologija: Uchebnikdlja vuzov [Stolyarenko, L.D. Psychology: Textbook for Universities]. Piter, 2008.

Strunkov, S. K. Processual'no-pravovye sredstva: problemy teorii $i$ praktiki. Pod red. A. V. Mal'ko [Strunkov, S.K. Legal Procedural Methods: Issues in Theory and Practice. Edited by A.V. Malko]. Saratov: Izd-vo GOU VPO "Saratovskaja gosudarstvennaja akademija prava”, 2005. 
Svencickij, A. L. Social'naja psihologija: Uchebnik [Sventsisky, A.L. Social Psychology: Textbook]. Moskva: TK Velbi, Izd-vo Prospekt, 2004.

Tkachev, N. I. Kachestvo processual'noj dejatel'nosti kak rezul'tat realizacii prava na sudebnuju zashhitu. Problemy i sootnoshenie [Tkachev, N.I. The Quality of Procedural Activities as a Result of Recognition of the Right for Judicial Protection. Issues and Values]. Teorija i praktika prava na sudebnuju zashhitu $i$ ee realizacija $v$ grazhdanskom processe. Mezhvuzovskij sbornik nauchnyh trudov [The Theory and Practice of the Right for Judicial Protection and Its Execution in the Civil Process. InterUniversity Collection of Scientific Research]. Saratov, 1991.

Topil'skaja, L. Kak nam obustroit' sudebnuju vlast' [Topilskaya, L. How We Should Organize Our Judiciary]. Rossijskaja justicija [Russian Justice]. 2000, 11: 13-15.

Trofimova, L. V. Osnovanija $k$ otmene sudebnyh reshenij, ne vstupivshih $v$ zakonnuju silu. Diss. ... kand. jurid. nauk [Trofimova, L.V. Grounds for Annulment of Court Rulings that Were not Legally Enforced. Diss. ... cand. legal sciences]. Saratov, 1999.

Vas'kovskij, E. V. Uchebnik grazhdanskogo processa. Izd. 2-e, pererabotannoe [Vaskovskyy, E.V. Textbook of Civil Process. 2nd edition, revised]. Moskva: Br. Bashmakovy, 1917.

Vas'kovskij, E. V. Uchebnik grazhdanskogo processa. MGU im. M. V. Lomonosova, jurid. fak., kaf. grazhdan. processa. - KubGU, jurid. fak., kaf. grazhdan. processa i trudovogo prava [Vaskovskyy, E.V. Civil
Process Tutorial. M.V. Lomonosov MSU, Legal faculty, dep. of civil procedure. KubSU, Legal. fac. dep. of civil procedure and Labor Law]. Krasnodar, 2003.

Vikut, M. A., and Zajcev, I. M. Grazhdanskij process Rossii: Uchebnik [Vykut, M.A., and Zaycev, I.M. Civil Procedure in Russia: Textbook]. Moskva: Jurist, 1999.

Vlasov, A. A. Grazhdanskoeprocessual'noe pravo: Uchebnik [Vlasov, A.A. Civil Procedure Law: Textbook]. Moskva: TK Velbi, 2004.

Voplenko, N. N. Oshibki v pravoprimenenii: ponjatie i vidy [Voplenko, N.N. Law Enforcement Errors: Concept and Types]. Sov. gosud. i pravo [Sov. State and Law]. 1981, 4: 38-46.

Voronov, A. F. Jevoljucija funkcional'nyh principov grazhdanskogo processa. Avtoref. dis. ... d-ra jurid. nauk [Voronov, A.F. The Evolution of Functional Principles of the Civil Process. Autoref. dis. ... of leg. studies PhD]. Moskva, 2009.

Zajcev, I. M. Teoreticheskie voprosy ustranenija sudebnyh oshibok $v$ grazhdanskom processe. Dis. d-ra jurid. nauk [Zaitsev, I.M. Theoretical Questions on Judicial Errors Elimination in Civil Proceedings. Dis. PhD legal sciences]. Saratov, 1986.

Zajcev, I. M. Sudebnye oshibki [Zaycev, I.M. Judicial Errors]. Sovershenstvovanie zakonodatel'stva $i$ pravoprimenitel'noj dejatel'nosti [Improving the Legislation and Law Enforcement Operations]. Jaroslavl', 1989, p. 90-94.

Zajcev, I. M. Teoreticheskie voprosy ustranenija sudebnyh oshibok $v$ grazhdanskom processe. Avtoreferat 
diss. ... d-ra jurid. nauk [Zaycev, I.M. Theoretic Questions on Judicial Error Elimination in Civil Proceedings. Autoref. diss. Phd in law science]. Saratov, 1987.

Zhilin, G. A. Celevye ustanovki grazhdanskogo sudoproizvodstva i problema sudebnoj oshibki [Zhylin, G.A. Target Regulations in Civil Proceedings and the Problem of
Judicial Error]. Gosudarstvo i pravo [State and Law]. 2000, 3: 51-58.

Zhilin, G. A. Zashhita prav cheloveka $\mathrm{v}$ grazhdanskom sudoproizvodstve [Zhylin, G.A. Protection of Human Rights in Civil Proceedings]. Rossijskaja justicija [Russian Justice]. 1998, 1: 5-7.

\title{
TEISMO KLAIDOS CIVILINIAME PROCESE: SAMPRATA, PRIEŽASTYS IR JŲ PREVENCIJOS PROCEDŪRINIAI METODAI
}

\author{
Nelia Savchyn \\ Černivcių Jurijaus Fedkovičiaus nacionalinis universitetas, Ukraina
}

Anotacija. Straipsnyje nagrinejjamas vienas iš negatyviuju teisinès sistemos aspektu - teismu klaidos. Šiame darbe analizuojamos skirtingos mokslininkų nuomonès dèl teismo klaidų kilimo priežasčiu ir pateikiamos autorès ižvalgos šiuo klausimu. Taip pat identifikuojami procedūriniai metodai, skirti teismo klaidu prevencijai, juos klasifikuojant, aprašant ir atskleidžiant ju svarbą civiliniame procese.

Reikšminiai žodžiai: sprendimas, priežastys, civilinis procesas, teisèjas, teismo klaida, teisingumas, prevencijos metodai.

\section{JUDICIAL ERRORS IN CIVIL PROCEEDINGS: CONCEPT, CAUSES AND PROCEDURAL METHODS OF THEIR PREVENTION}

\author{
Nelia Savchyn \\ Yuriy Fedkovych Chernivtsi National University, Ukraine
}

Summary. This article defines the notion of judicial error, which is an unlawful (inaction) of the authorized entity (the judge), occurring regardless of his intention, outlined in a specific procedural document, that violates the procedural and (or) substantive laws, results in a failure to achieve the goals and carry out the duties of the procedural litigation, as a result of which a specific court ruling can be vitiated or 
modified either by a higher court or by the issued court (correction of typographical and arithmetic errors, additional ruling, judgement clarification).

There are no occurrences or events in the world that would not have a cause for their emergence or existence. A judicial error also has defined reasons of its emergence and existence. The analysis of causes of judicial errors has an important practical meaning as it allows creating methods of organisational, legal and procedural character for elimination and prevention of judicial errors. Identifying the causes of judicial errors is useful not only for elimination of judicial errors, but also for prevention of their occurrence.

The causes of judicial errors include the following: 1) inadequate level of education and training of judges; 2) lack of appropriate moral qualities of judges; 3) lack of knowledge of substantive and procedural law; 4) dishonesty, superficial, careless and formal attitude of judges towards their duties; 5) inability to organize their work correctly; 6) careless filing of procedural documents; 7) absence of job experience; 8) ignorance of higher court clarifications on the application of state law; 9) subjective views, likes and dislikes of judges; 10) low level of judges' discipline; 11) the bias of the court; 12) violation of statutory procedural terms, etc.

Removing judicial errors through vitiation and modification of the ruling is an undesired extreme measure as an act of justice and it should not be viewed as a standard occurrence (in terms of legal regulation), but rather as an exceptional one. Thus, it is evident that in order to increase the effectiveness of civil litigation, preventive methods should be considered equally important to the elimination methods of judicial errors.

Procedural methods of judicial errors prevention in civil litigation are specific provisions of the Civil Procedure Law, the execution of which significantly hurdles the occurrence of judicial errors in civil proceedings.

One of the most effective methods of increasing the effectiveness of justice system in civil proceedings includes the following:

- the right to recast judges;

- consideration of cases by a panel of judges;

- rendering a ruling in the jury room;

- institutional structure of the court system;

- the concept of direct court investigation;

- transparency and openness of the justice system;

- compilations of judicial practice by higher courts.

Keywords: adjudication, causes, civil litigation, judge, judicial error, justice, occurrence, preventive methods.

Nelia Savchyn, Černivcių Jurijaus Fedkovičiaus nacionalinio universiteto Teisès fakulteto Teisingumo katedros mokslo darbuotoja. Mokslinių tyrimų sritis: civilinis procesas.

Nelia Savchyn, Yuriy Fedkovych Chernivtsi National University, Faculty of Law, Department of Justice, Research Assistant. Research interests: Civil Procedure. 